doi.org/10.46291/ISPECIJSSHvol4iss3pp212-240

\title{
Rekreasyonel Amaçlı Motor Kullanıcılarının Profilleri: Türkiye Örneği ${ }^{1}$
}

\author{
Prof. Dr. Faik ARDAHAN \\ Akdeniz Üniversitesi, Spor Bilimleri Fakültesi \\ Rekreasyon Bölümü, Antalya/Türkiye, ardahan@akdeniz.edu.tr
}

\section{Selçuk GÜLEÇ}

Hüseyin Ak Ortaokulunda Beden Eğitimi Öğretmeni

Antalya/Türkiye, selcukgulec07@gmail.com

\section{Özet}

Araştırmanın amacı; Türkiye'deki Rekreasyonel Amaçlı Motor Kullanıcılarının Profillerini belirlemektir. Araştırma tanımlayıcı bir araştırmadır ve örneklem tüm Türkiye genelinden 947 kişiden oluşmaktadır. Veri toplama aracı olarak araştırmaya özel olarak geliştirilen anket formu kullanılmış ve veriler sosyal medya üzerinden 1 Şubat 2017 - 30 Haziran 2017 tarihleri arasında elektronik anket aracılığıyla toplanmıştır ve çalışmada tanımlayıcı istatistikler kullanılmıştır. Motor kullanıcılarının iyi eğitim düzeyinde, erkek, orta yaş düzeyinde, orta düzeyde gelire sahip, kamu ve özel sektörde çalışan, Enduro, Scooter, Turing/Sport Touring tarzı motor kullanan bireylerden oluştuğu, gelirlerinin önemli kısmını motor için harcadıkları, motor kullanmaya kendilerinin karar verdikleri, motor etkinliklerine motor kullanan arkadaşlarıyla veya yalnız gittikleri, serbest zamanlarında internette gezinmek, evde dinlenmek gibi daha çok pasif etkinliklere katıldıkları, ağırlıklı olarak doğa sporları ve fitness merkezlerinde yapılan sporları yaptıkları, TV'de Belgesel ve Haber programları izledikleri, aile bireylerinden kardeşlerinin motor kullanıyor olduğu, serbest zamanlarında çok fazla kitap okumadıkları, sinemaya gitmedikleri, TV izlemedikleri, ama bunun tersine ağırlıklı olarak motor hakkında konuştukları, motor kullanmak konusunda iyi olsalar da bunun yeterli olmadığını, kendilerini geliştirmek istedikleri, güvenliğe önem verdikleri, Özgürlük Hissi Verdiği, Yenilenmiş Tazelenmiş Hissettirdiği, Günlük Rutinden Uzaklaştırdığ için motor kullandıkları bulgulanmıştır. Sonuç olarak; motor kullanmanın önemli bir ekonomik değer yarattığı, motor kullanıcıları bilinçli olmakla birlikte trafikte hala çok sayıda bilinçsiz motor ve araba kullanıcısının olduğu, bunun için mutlaka motor kullanıcılarına ileri sürüş, diğer araç sürücülerine trafikte saygilı olma eğitimlerinin verilmesi gerektiği, motor kullanmanın da bir yaşam biçimi olduğu söylenebilir.

Anahtar Kelimeler: Motosiklet, Motor Kullanımı, Profil, Rekreasyon

1. Bu çalışma; "International Congress on Recreation and Sport Management. 10-13 th May 2018. La Blanche Island Hotel, Bodrum, Muğla, Turkey” de sözlü bildiri olarak sunulan çalışmanın geliştirilmiş halidir.

Year 4/ 2020, Volume-4, Issue-3 | WWW.ispecjournal.org 


\title{
The Profile of Recreational Motorcycle Users: Turkey Case
}

\begin{abstract}
The main aim of this research was to identify the profile of the Recreational Motorcycle Users in Turkey. The research was descriptive and sampling group was consisted of 947 participants all around Turkey. Data was collected by using questionnaire form developed for specifically for this research with electronic survey on social media between 1th February 2017- 30 th June 2017. In the processing of data, descriptive statistic methods have been used. The findings show that recreational motor users were well educated, men, average aged, have average monthly income, employed in private and public sector, using Endure, Scooter and Turing/Sport Touring motor types, spent $15 \%$ of their annual income, decided to use motor by themselves, prefer to participate in motor activities with alone and/or other motor users, to waste their free time in passive activities like surfing and resting in home, but some prefer outdoor sports and fitness centers, watching documentaries and newscasts on TV, also some of their brother/sisters use motor, not prefer reading books, going cinemas, watching TV, but they spent most of spare time by talking about motors, even if they have enough specialization on motor usage and safety, they want advanced driving courses. Their most important motivational reasons for using motor were feeling freedom, get renewed and refreshed feelings, and escape from daily routine. As a result, it can be concluded that recreational motor usage is a life style and creates a big economic impacts, even if they define themselves as conscious motor user, they state there are numerous unconscious motor user and drivers in daily traffics, and must be given courses about advanced driving, safety and responsibility of respect.
\end{abstract}

Key Words: Motorcycle, Motor Usage, Profile, Recreation

\section{Giriş}

İnsan gücüyle çalışan bisikletin icadından sonra insanoğlu o dönemlerde yeni yeni vücut bulan motor gücüyle bu bisikleti hareket ettirtmeyi istemiş ve günümüzdeki motorlara tam olarak da benzemese de motorların atası sayılacak ilk tasarım gücünü üzerindeki buhar motorundan alan 1868 yılında Michaux Perreaux tarafından geliştirilmiştir. Otomobillerin de gelişmesiyle günümüz anlamındaki motorların ilk tasarımı sayılabilecek tahta tekerli model Daimler Reitwagen tarafından 1885 yılında yapılmıştır. Lastik tekerli ilk model John Boyd 
Dunlop tarafından 1888 yılında üretilmiştir. Motosikletin yaşam biçimine dönüşmesi 1903 yılında William Harley, Arthur ve Walter Davidson'un bir araya gelerek kurdukları Harley Davidson marka motorların üretilmesiyle ve pazarlanmasıyla başlamıştır. 1912 yılında Carl Stearns Clancy ve Walter Storey 10 ay süren bir yolculukla 30bin km'lik yolculukla dünyayı ilk dolaşan kişiler olmuşlardır. Birinci ve İkinci Dünya Savaşında motorlar askeri alanda da kullanılmıştır. 1950'li yıllar motorların dönüm noktasıdır. Hem üretimlerinde hem pazarlamalarında muazzam bir dönüşüm yaşanmış ve bu değişim günümüzde de devam etmektedir² ${ }^{2}$ Özellikle Amerika'da hız yapan olan her şeyin yarıştırıldığı dünya da motorlar Show ve yarış amaçlı kullanılmaya 1939 yılında Grand Prix pistinde kullanılarak başlanmıştır. DRAG yarışlarının yapıldığı pistte o yıllarda denenen finişteki hızı $350 \mathrm{~km} / \mathrm{h}$ a ulaşan Tony Lang'ın kullandığı 800 beygir gücündeki nikrometan yakan Suzuki GSX $1100{ }^{\prime} \mathrm{dür}^{3}$.

Kullanıcıların hız tutkusu, yeterli güvenlik önlemi almadan yapılan sürüşler, güvenli olmayan sürüşler, alkollü motor kullanımı, trafikte motor kullanıcılarına gösterilmeyen saygı gibi nedenlerle yüksek sürüş riski olan hatta "Ölüm Makinası" olarak tanımlanan motosiklet (Schneider IV ve ark. 2012) günümüzde hayatın olduğu her yerde taşıt olarak kullanılmakta, verdiği sürüş keyfi, hıza bağlı adrenalin, tatmin duygusu gibi nedenlerden dolayı ülkemizde Tablo-1- ve tüm dünya genelinde kullanıcılarının sayısı giderek artmaktadır. Özellikle trafik yoğunluğunun olduğu şehirlerde, özel araç kullanımının zorluğu, akaryakıt ve park maliyetlerinin yüksekliği, toplu taşım araçlarının kalabalık, yavaş ve havasız olması bireyleri motosiklet kullanımına ya da bisiklet kullanımı gibi daha bireyselleşmiş araçlara yöneltmektedir (Haworth, 2012; TUIK, 2018a).

\footnotetext{
2 - https://www.motorcular.com/tr/moto-bilgi/motosikletin-tarihi- (Okunma Tarihi: 7 Nisan 2018)

${ }^{3}$ - http://www.forumgercek.com/motor-sporlari-motorsiklet-dunyasi/40343-motosiklet-tarihi-ve-kronolojsi.html (Okunma Tarihi: 7 Nisan 2018)

Year 4/ 2020, Volume-4, Issue-3 | WWW.ispecjournal.org
} 


\begin{tabular}{|c|c|c|c|c|c|c|c|c|}
\hline Yll & Toplaml & Toplam2 & Otomobil & Motosiklet & Oran01 & Oran02 & Oran03 & Oran04 \\
\hline 2002 & 8.655 .170 & 5.647 .047 & 4.600 .140 & 1.046 .907 & 18,54 & 81,46 & 12,10 & 53,15 \\
\hline 2003 & 8.903 .843 & 5.773 .758 & 4.700 .343 & 1.073 .415 & 18,59 & 81,41 & 12,06 & 52,79 \\
\hline 2004 & 10.236 .357 & 6.619 .117 & 5.400 .440 & 1.218 .677 & 18,41 & 81,59 & 11,91 & 52,76 \\
\hline 2005 & 11.145 .826 & 7.213 .811 & 5.772 .745 & 1.441 .066 & 19,98 & 80,02 & 12,93 & 51,79 \\
\hline 2006 & 12.227 .393 & 7.963 .823 & 6.140 .992 & 1.822 .831 & 22,89 & 77,11 & 14,91 & 50,22 \\
\hline 2007 & 13.022 .945 & 8.475 .648 & 6.472 .156 & 2.003 .492 & 23,64 & 76,36 & 15,38 & 49,70 \\
\hline 2008 & 13.765 .395 & 8.978 .012 & 6.796 .629 & 2.181 .383 & 24,30 & 75,70 & 15,85 & 49,37 \\
\hline 2009 & 14.316 .700 & 9.397 .225 & 7.093 .964 & 2.303 .261 & 24,51 & 75,49 & 16,09 & 49,55 \\
\hline 2010 & 15.095 .603 & 9.934 .359 & 7.544 .871 & 2.389 .488 & 24,05 & 75,95 & 15,83 & 49,98 \\
\hline 2011 & 16.089 .528 & 10.640 .301 & 8.113 .111 & 2.527 .190 & 23,75 & 76,25 & 15,71 & 50,42 \\
\hline 2012 & 17.033 .413 & 11.306 .597 & 8.648 .875 & 2.657 .722 & 23,51 & 76,49 & 15,60 & 50,78 \\
\hline 2013 & 17.939 .447 & 12.006 .749 & 9.283 .923 & 2.722 .826 & 22,68 & 77,32 & 15,18 & 51,75 \\
\hline 2014 & 18.828 .721 & 12.686 .381 & 9.857 .915 & 2.828 .466 & 22,30 & 77,70 & 15,02 & 52,36 \\
\hline 2015 & 19.994 .472 & 13.527 .701 & 10.589 .337 & 2.938 .364 & 21,72 & 78,28 & 14,70 & 52,96 \\
\hline 2016 & 21.090 .424 & 14.321 .731 & 11.317 .998 & 3.003 .733 & 20,97 & 79,03 & 14,24 & 53,66 \\
\hline 2017 & 22.218 .945 & 15.138 .778 & 12.035 .978 & 3.102 .800 & 20,50 & 79,50 & 13,96 & 54,17 \\
\hline $2018^{(1)}$ & 22.377 .559 & 15.249 .541 & 12.141 .248 & 3.108 .293 & 20,38 & 79,62 & 13,89 & 54,26 \\
\hline \multicolumn{9}{|c|}{$\begin{array}{l}\text { TÜİK, Motorlu Kara Tașıtları, Şubat } \mathbf{2 0 1 8} \\
\text { Toplam1= Kamyon, Kamyonet, Traktör dahil tüm motorlu kara taşıtlarının toplam sayısı } \\
\text { Toplam2= Sadece Otomobil ve Motosikletlerin toplam sayısı }\end{array}$} \\
\hline \multicolumn{3}{|c|}{$\begin{array}{l}\text { Oran1= Toplam2'ye göre Motosiklet oranı } \\
\text { Oran2= Toplam2'ye göre Otomobil oranı } \\
\text { Kaynak: (TUIK, 2018a) }\end{array}$} & \multicolumn{6}{|c|}{$\begin{array}{l}\text { Oran3 }=\text { Toplam1'e göre Motosiklet oranı } \\
\text { Oran4= Toplam1'e göre Otomobil oranı }\end{array}$} \\
\hline
\end{tabular}

Tablo-1'de verilen rakamlara bakıldığında Türkiye'deki motor kullanımı 2002 yılından itibaren durağan bir değişim oranı içindeyken 2006 yılından itibaren ciddi bir artışın içinde olmuş o yıllarda göreceli olarak da otomobil satışları azalmıştır. 2014 yılına kadar bu değişim motosiklet lehine iken bu yıldan itibaren otomobil lehine bir değişim olmuştur. Bu haliyle Türkiye'deki motorlu kara taşıtları içinde motosikletin payının ortalama \%14, otomobilin \%54, özel ulaşım araçları olan otomobil ve motosiklet toplamı içinde motosikletin payı \%20, otomobilin ise \%80 olduğu söylenebilir.

Motosiklet, 2918 sayılı Karayolları Trafik Kanunu 3. Maddede tanımlandığı biçimiyle taşıt olarak kabul edilir ve kullanımı lisans gerektirir. Diğer tüm taşıtlar için de geçerli olan yasal mevzuata tabidir ve dört farklı kullanım biçimiyle bireyin hayatında yer almaktadır; a) tüm güvenlik önlemleri alınmış trafiğe kapalı alanlarda, gösteri, yarışma ve rekabet amaçlı kullanım biçimi olan Profesyonel Kullanım (Professional Usage), b) kargo, paket taşımacılı̆̆ 1 , taksi, teslimat, gibi bireylerin ve eşyaların taşınması amacıyla kullanım biçimi olan Ticari Kullanım (Commercial Usage), c) bireylerin gündelik hayatlarında trafik yoğunluğundan kurtulmak, toplu taşım araçlarının kalabalık, yavaş ve havasız ortamından kurtulmak, daha zamanlı ve hızlı bir ulaşım sağlamak amacıyla hem şehir içi hem de 
şehirlerarası yollarda Ulaşım Amaçı Kullanım (Commute / Transportation Usage), d) sürüş keyfi yaşamak, hobi amaçlı, bir yere ulaşmak, görmek, gezmek gibi rekreasyonel hayatın parçası olarak kullanımı olan Rekreasyonel Kullanım (Recreational Usage) olarak sınıflanır (Haworth, 2012; Strutter, 2010).

Motorun profesyonel kullanımı "Motor Sporları" üst başlığında yarışmacı bir spor olarak karşılığını bulur. Hız, dayanıklılık, estetik, zorlukla baş edebilme gibi birçok engeli aşarak yarışa dayalıdır. Ülkemizde 1967 yılında başlayan motosiklet sporu önce Bisiklet Federasyonu içinde, 1995-2003 yılları arası Otomobil Sporları Federasyonu içinde 2003 Ağustosu başından buyana Türkiye Motosiklet Federasyonu çatısı altında yapılmaktadır. Federasyonun amac1; Motosiklet sporu Pist, Süper Enduro, Enduro, ATV, Süpermoto, Motokros, Drag, ve Sujeti kategorilerinde ister pistte isterse özel düzenlenmiş doğa alanlarında veya offroad alanlarında yapılsın hem izleyenler ham de yarışçılar için yüksek düzeyde adrenalin içerir ve görsel zenginlik ve seyir zevki verir. Ülkemizin her yerinde özellikle de büyükş̧ehirlerde ulusal/bölgesel düzeyde yapılan organizasyonlar hem motorsiklet kültürünün yerleşmesine(gelişmesine katkı sağlamakta hem de motor sürücülerinin yaşam kaliteleri üzerinde iyileşme sağlamakta, motorsporları kulüplerinin gelişmesine ve sporun yaygınlaşmasına katkı sağlamakta, tehlikeli sürüşlerden ve zararlı alışkanlıklardan bireyleri korumakta ve bu alanda geleceğe yatırım yapmaktadır ${ }^{4}$.

Motorun profesyonel, ulaşım ve ticari amaçlı kullanımı rekreasyonel kullanımına dâhil değildir. Bu kullanım biçimlerindeki ayrımı da yapmak oldukça zordur. Hafta içi iş-ev arası ulaşım amaçlı kullanan kişi veya motoruyla kargo taşımacılı̆̆ı yapan birinin hafta sonları veya mesai dışında gezmek amaçlı kullanımı rekreasyonel sürüş olarak kabul edilebilir (Ardahan ve Güleç, 2017). Motorun rekreasyonel kullanımı bireylerin yaşam biçiminin tamamını veya önemli bir kısmını tarif eden, tamamen keyif almak amaçlı veya rekreasyonel amaçlı yapılan her faaliyetin parçası olarak sürüşleri kapsar. Örneğin balık avlamak için denize, nehre gidiş, kaya tırmanışı yapmak için kaya tırmanışı yapılacak yere ulaşım amaçlı gidiş rekreasyonel sürüşe dâhil edilebilir. Rekreasyonel motor kullanımının üç farklı formu vardır. Birey eğer firsat buldukça motor kullanıyorsa bu kullanıma Spontane Kullanım, Belli gün ve haftalarda bir projenin parçası olarak kullanıyorsa, bu kullanıma Proje Biçimli Kullanım, birey bir yaşam biçimi ve kimliğinin parçası olarak gördüğü, kendini tanımladığı Ciddi Boş Zaman Faaliyeti olarak kullanımdır (Ardahan ve Güleç, 2018).

4 - https://www.tmf.org.tr/tmf/tmf-hakkinda/

Year 4/ 2020, Volume-4, Issue-3 | WwW.ispecjournal.org 
Motorun rekreasyonel, ulaşım ve ticari amaçlı kullanımındaki yaygınlaşma motor kazalarındaki sayısı arttırmıştır (Daniello ve ark. 2009; Huth ve ark. 2014). Yapılan bilimsel çalışmalarda motorsikletin binek araçlara göre 35 kat daha ölümcül risk içerdiği, yaralanma riskinin ise sekiz kat fazla olduğu ABD'de yayımlanan National Highway Traffic Safety Administration'ın (NHTSA) 2007 raporunda raporlanmıştır (Koçak ve ark. 2010).

Tablo-2'de görüldüğü gibi; yıllar itibariyle ölümlü ve yaralanmalı motor kazaları sayısında ciddi bir artış vardır. Yıllar itibariyle kaza oranlarında özel bir artış olmasa da kazalardaki ölen sayısı ve yaralanma sayısında ciddi bir artış vardır. Bunun en önemli nedeni güvenli sürüş tekniklerini uygulamamak ve güvenlik ekipmanlarına sahip olmamaktır. Bunun önüne geçilmesinde sadece motor kullanıcılarını eğitmek yeterli değildir. Motor kazalarının önemli sebeplerinden biri de trafikteki diğer taşıtların neden olduğu kazalardır. Elbette motor kullanıcıları ileri ve güvenli sürüş teknikleri konusunda, güvenlik ekipmanlarına sahip olma konusunda ciddi bir bilinçlendirme çalışmaları yapılmaktadır. Ama trafikteki diğer sürücülerin eğitilmesi ve bilinçlendirilmesinde istenilen başarıya ulaşıldığından henüz söz edilemez. Bunlara ilave olarak, motor kazaların ölüm ve yaralanma gibi olumsuz etkilerinin yanında milli servet kaybına da yol açtığı söylenebilir.

Tablo-2: Yıllar İtibariyle Türkiye'deki Ölümlü/Yaralanmalı Motosiklet Kaza Sayıları

\begin{tabular}{lllllll}
\hline Yıl & $\begin{array}{l}\text { Trafikteki } \\
\text { Motor Sayısı }\end{array}$ & $\begin{array}{l}\text { Toplam } \\
\text { Sayısı ve oranı }\end{array}$ & $\begin{array}{l}\text { Sürücü } \\
\text { Sürücü }\end{array}$ & $\begin{array}{l}\text { Yaralanan } \\
\text { Ölüm (\%) }\end{array}$ & $\begin{array}{l}\text { Motor Başına } \\
\text { Yaralanma(\%) }\end{array}$ \\
\hline $\mathbf{2 0 1 3}$ & 2.722 .826 & $40.699 \% 1,495$ & 292 & 35.131 & 0,011 & 1,290 \\
$\mathbf{2 0 1 4}$ & 2.828 .466 & $43.059 \% 1,522$ & 333 & 37.119 & 0,012 & 1,312 \\
$\mathbf{2 0 1 5}$ & 2.938 .364 & $46.310 \% 1,576$ & 880 & 39.368 & 0,030 & 1,340 \\
$\mathbf{2 0 1 6}$ & 3.003 .733 & $46.481 \% 1,547$ & 948 & 39.729 & 0,032 & 1,323 \\
\hline
\end{tabular}

Not: Veriler Yıllar İtibariyle Verilen TUIK istatistiklerinden alınarak tablo oluşturulmuştur

Motor kazalarında kazalara neden olan etmenlerle ilgili özel bir istatistik TUIK verilerinde yoktur. Fakat Tablo-3'de verildiği gibi motorlu taşıt kazalarına sebep olan etmenler \%90 oranla sürücü hatası, \%10'da taşıttan, yoldan, yolcudan, yayadan kaynaklı hatalardır. TUIK sürücü hatalarını şu şekilde özetlemiştir5; a) alkollü araç kullanmak, b) araç hızını hava ve trafiğin gerektirdiği şartlara uydurmamak, c) arkadan çarpmak, d) aşırı hızlı araç kullanmak, e) dönüş kurallarına uymamak, f) geçme yasağı olan yerlerde kural ihlali, g) kavşaklarda geçiş

\footnotetext{
5- http://www.tuik.gov.tr/PreHaberBultenleri.do?id=24606

Year 4/ 2020, Volume-4, Issue-3 | WWW.ispecjournal.org
} 
önceliğine uymamak, h) 1şıklandırma ve görevlinin dur işaretine uymamak, i) kurallara uygun park etmiş araçlara çarpmak, j) manevraları düzenleyen genel şartlara uymamak, k) şerit ihlali yapmak, 1) taşıt giremez işareti bulunan yerlere girmek, m) yaya ve okul geçitlerinde yavaşlamamaktır. Yolcu kusurları; a) kask kullanmamak, b) emniyet kemeri takmamak, c) araçlara kontrolsüz şekilde binmek ve inmek, d) trafiği güçleştirecek şekilde yola bir şey atmak-dökmek, e) alkollü olarak seyahat etmektir. Yaya kusurları; a) geçit ve kavşakların bulunmadığı yerlerde geçme kurallarına uymamak, b) trafik 1şık ve işaretlerine uymamak, c) taşıt yolu üzerinde trafiği tehlikeye düşürücü hareketlerde bulunmak, d) karşıdan karşıya geçişlerde trafik kurallarına uymamak, e) taşıt yoluna girmek, f) taşıt yolunda sol kenardan gitmemek, g) gece ve gündüz görüşün az olduğu hallerde çarpmayı önleyici tedbirler almamak, h) trafiğgi güçleştirecek şekilde yola bir şey atmak-dökmek, i) alkollü yola çıkmaktır. Yol kusurları; a) tekerlek izinde oturma, b) şerit çökmesi, c) kısmi veya münferit çökme, d) düşük banket, e) yol sathında gevşek malzeme, f) yolda münferit çukurdur. Taşıt kusurları ise güvenli sürüşü, manevrayı, duruşu etkileyen donanım hatalarıdır.

Tablo-3: TUIK Verilerine Göre Yıllar İtibariyle Kaza Sebepleri

\begin{tabular}{|c|c|c|c|c|c|c|c|c|c|c|c|}
\hline Y11 & $\begin{array}{l}\text { Toplam } \\
\text { Kusur }\end{array}$ & $\begin{array}{l}\text { Sürücü } \\
\text { Hatas1 }\end{array}$ & $\%$ & $\begin{array}{l}\text { Yolcu } \\
\text { Hatas1 }\end{array}$ & $\%$ & $\begin{array}{l}\text { Yol } \\
\text { Hatas1 }\end{array}$ & $\%$ & $\begin{array}{l}\text { Taşıt } \\
\text { Hatas1 }\end{array}$ & $\%$ & $\begin{array}{l}\text { Yaya } \\
\text { Hatas1 }\end{array}$ & $\%$ \\
\hline 2009 & 155.982 & 139.758 & 89,60 & 640 & 0,40 & 958 & 0,60 & 445 & 0,30 & 14.181 & 9,10 \\
\hline 2010 & 157.970 & 141.728 & 89,70 & 564 & 0,40 & 992 & 0,60 & 515 & 0,30 & 14.171 & 9,00 \\
\hline 2011 & 174.605 & 157.494 & 90,20 & 677 & 0,40 & 1.044 & 0,60 & 530 & 0,30 & 14.860 & 8,50 \\
\hline 2012 & 181.266 & 161.076 & 88,90 & 797 & 0,40 & 1.124 & 0,60 & 597 & 0,30 & 17.672 & 9,70 \\
\hline 2013 & 183.030 & 162.327 & 88,70 & 774 & 0,40 & 1.913 & 1,00 & 1.558 & 0,90 & 16.458 & 9,00 \\
\hline 2014 & 193.215 & 171.236 & 88,60 & 901 & 0,50 & 1.841 & 1,00 & 1.122 & 0,60 & 18.115 & 9,40 \\
\hline 2015 & 210.498 & 187.980 & 89,30 & 915 & 0,40 & 1.916 & 0,90 & 1.165 & 0,60 & 18.522 & 8,80 \\
\hline 2016 & 213.149 & 190.954 & 89,60 & 869 & 0,40 & 1.717 & 0,80 & 997 & 0,50 & 18.612 & 8,70 \\
\hline
\end{tabular}

Not: Veriler Yıllar İtibariyle Verilen TUIK istatistiklerinden alınarak tablo oluşturulmuştur 
Güvenli sürüş konusunda dünya genelinde yapılan çalışmalar kaza oranlarını aşağı çekmeye yetmemekte. Bu konuda tüm sürücülerin ciddi şekilde eğitilmeye ihtiyacı vardır ${ }^{6}$. Diğer taşıt araçlarıyla karşılaştırıldığında kaza riskinin yüksek olması ve kaza bedelinin ağır sonuçlar doğurması yanında başka hiçbir dezavantajı olmayan motosikletin avantajı yanları ${ }^{7}$;

- Şehir içi ve dışı ulaşım amaçlı kullanımda kompaktır.

- Her bütçe için ulaşılabilirdir.

- Diğer taşıt araçlarına göre düşük karbon salınımına sahiptir. Kullanıcısını çevreye ve doğaya karşı daha duyarlı hale getirir.

- Trafik karmaşası sorununa çözüm alternatifidir.

- Hafifliği nedeni ile asfalt ve yol kaplamalarına zarar vermez, ekonomiye katkı sağlar.

- Tamir, bakım ve onarım masrafları düşük olması güvenlik anlamında bakımlı tutulabilen bir araçtır.

- Hem ulaşım hem de rekreasyonel olarak da tercih edilir.

- Rekreasyonel anlamdaki kullanım turizme katkı sağlar.

- Ulaşım ve trafik anlamında medeniyet göstergesidir.

- Ulaşım sektöründe yerli üretimde, bisikletten sonra, en yüksek paya sahip araçtır.

- Trafik ve güvenlik bilincini yaratır ve sürdürür.

- Daha az park alanına ihtiyaç duyar bu sebeple araç yoğunluğu fazla olan şehirlerde park sorununa çözüm sağlar.

- Hem zihinsel hem de fiziksel olarak kullanıcıya dinç ve sağlıklı olma firsatı yaratır.

Chang ve Lai'nin de (2015) belirttiği gibi motor kullanıcıları ile motor arasında duygusal ve psikolojik bir bağ oluşmakta, bireyler, motorlarını "iki teker" olarak ifade etseler de o artık onlar için bir taşıt değil sürücülerinin "kanatlarıdır". Hatta Ardahan ve Güleç (2017) motor kullanıcılarının motorlarını bir taşıttan daha fazlasını gördüklerini, çoğu zaman arkadaşları, yoldaşları, sırdaşları olarak gördüklerini belirtmişlerdir. Bu tanımlamalar Steg ve arkadaşları (2001) ve Steg'in (2005) ortaya koydukları "Taşıt Kullanım Teorisinde- Motivation for Vehicle Use Theory" belirttikleri gibi, bireyleri araç kullanımına veya sahibi olmaya motive eden üç temel boyutla örtüşmektedir. Taşıt Kullanım Teorisinde bu boyutlar kişiden kişiye göre değişse de özellikle bireylerin motor sahibi olma gerekçelerini tanımlamakta ve bu

\footnotetext{
6 - http://www.motosiklet.net/forum/moto-sohbet/145396-turkiye-ve-dunyada-trafik-kaza-istatistikleri-olumoranlari-vs-2007-2013-icerir.html (Okunma Tarihi: 9 Nisan 2018)

7 - http://www.uludag.edu.tr/dosyalar/ziraat/EgitiminOnemi.pdf (Okunma Tarihi: 9 Nisan 2018)

Year 4/ 2020, Volume-4, Issue-3 | WWW.ispecjournal.org
} 
gerekçeler motor üreticilerinin pazarlama stratejilerini oluşturmada vurgulanan gerekçelerini oluşturmaktadır. Bu boyutların ilki bir taşııın bireyin hayatına getireceği hız, seyahat esnekliği, seyahat zamanı, maliyeti, kolay ulaşılırlığı olarak görülen Araçsal Boyut, ikincisi; yarattığı sürüş keyfi, beraber yapabildiklerinden dolayı hissettirdiği heyecan, zevk, coşku gibi duygulardan oluşan Duygusal Boyutu, üçüncüsü; bireyin yaşam biçimiyle bütünleşen, kimliğiyle bütünleşen veya onları oluşturan, ayırt edicisi, kişisel imajın sembolü, sosyal statü değeri gibi bir aracın/eşyanın bireyde yarattığı psikolojik etkileri tarifleyen Sembolik Boyutudur.

Farklı motor tarzlarının varlığı aslında daha çok kullanıcılarının yaşam biçimleri ve motordan beklentileriyle (talebin çekmesi) oluşsa da ve arzın itmesi de farklılaşma sebebi olarak ele alınabilir (Krige, 1995; Ardahan ve Güleç 2017). Arzın itmesi aynı zamanda daha çok kullanıcıların her sürüş tarzı için ayrı motor alması yerine motor tarzlarının kombine edilmesiyle oluşmaktadır (Ardahan ve Güleç, 2018).

İlk sürüş tarzı farklılaşması Harley Davidson'ın Chopper tarzı motorla başlayan daha sonra maceracıların istedikleri güçlü sağlam motorlar segmentinde Kros Motorlar, uzun yol sürüşünde konfor sağlayan Touring motorlar, spor kullanımda hızı ön planda olan Racing veya Super Sport tarzı motorlar, hem hız hem de uzun yol sürüşü keyfi sağlayan Sport Touringler, Hem uzun yol sürüşü hem de arazide avantaj yaratan Enduro tarzı motorlar, çoğunlukla şehir içi ulaşım amaçlı ve düşük yakıt tüketimli Scooterlar, üzerinde hiçbir aksesuarı olmayan ve oturuş pozisyonu itibariyle yarış motorlarından ayrılan Naked motorlar aslında kendiliğinden kullanım tarzı farklılaşması yaratmaktadır ${ }^{8},{ }^{9}$. Motorcuları; yaşam tarzları, kişilik özellikleri, motordan beklentileri açısından sınıflandığında, a) "Bikie Group" olarak da tanımlanan otoriteye karşı çıkan kullanıcılar, b) hızı seven, çoğunlukla az tecrübeli "Harika çocuk- boy wonder" olarak tariflenen kullanıcılar, c) zoru, mücadeleyi seven, inatçı, kolay vazgeçmeyenler olarak tanımlanan "İnatçılar- Dirts" kullanıcılar, d) motoru sadece ulaşım amaçlı kullananlar, e) daha çok şehir dışı ve rekreasyonel amaçlı sürüşler için kullanılan "Hafta Sonu Kullanıcılar1- Weekend Warriors" (Krige, 1995).

Motorun her tür kullanımı üretiminden dağııımına, servis, yedek parça, yakıt, ekipman, aksesuar, eğitim, yarış alanları, sigorta, motor türlerinin yarattığı TV dahil etkilediği medya, eğlence yerleri, kafeler, restoranlar, kulüpler dahil birçok sektörü içine alan muazzam büyüklükteki bir pazarı tarif eder. Her ülke ülkeler kendi markalarını yaratsa da Çin, Tayvan,

\footnotetext{
8 - https://www.motorcular.com/tr/moto-bilgi/motosiklet-turleri (Okunma Tarihi: 9 Nisan 2018)

9 - https://www.bizevdeyokuz.com/motosiklet-cesitleri/ (Okunma Tarihi: 9 Nisan 2018)

Year 4/ 2020, Volume-4, Issue-3 | WWW.ispecjournal.org
} 
Tayland, Güney Kore, Vietnam, Hindistan, Endonezya, Pakistan, Filipinler, Japonya, Avrupa Birliği Ülkeleri, A.B.D. gibi devlerin rol aldığı bu pazarda oyuncu olmak oldukça büyük finansal güç gerektirmektedir. Örneğin, Şekil-01, ABD pazarında sadece motor satışlarıyla yaratılan gayri safi hasılanın 2016 yı1ı büyüklüğü Toplam 487bin yeni motor satışı yapılarak ${ }^{10}$ yaratılan 7.31 milyar $\$ d_{11}{ }^{11}$. Duprey'in (2017) çalışmasında verdiği değerlere bakıldığında ABD’de 2015 yılında tüm motor sektöründe yaratılan toplam Gayrisafi Hasıla 24.1 milyar\$'dır ve sektörde toplam 81bin kişiye istihdam yaratmıştır. Türkiye'de 2018- Şubat verilerine göre pazardaki motosiklet sayısı 3.108.293 adet, 2017 yılında toplam 398.121 adet motor el değiştirmiştir (TUIK, 2018b).

\section{Şekil-01: ABD Motor Pazarı Büyüklüğü (Gayrisafi Hasıla-milyar\$)}

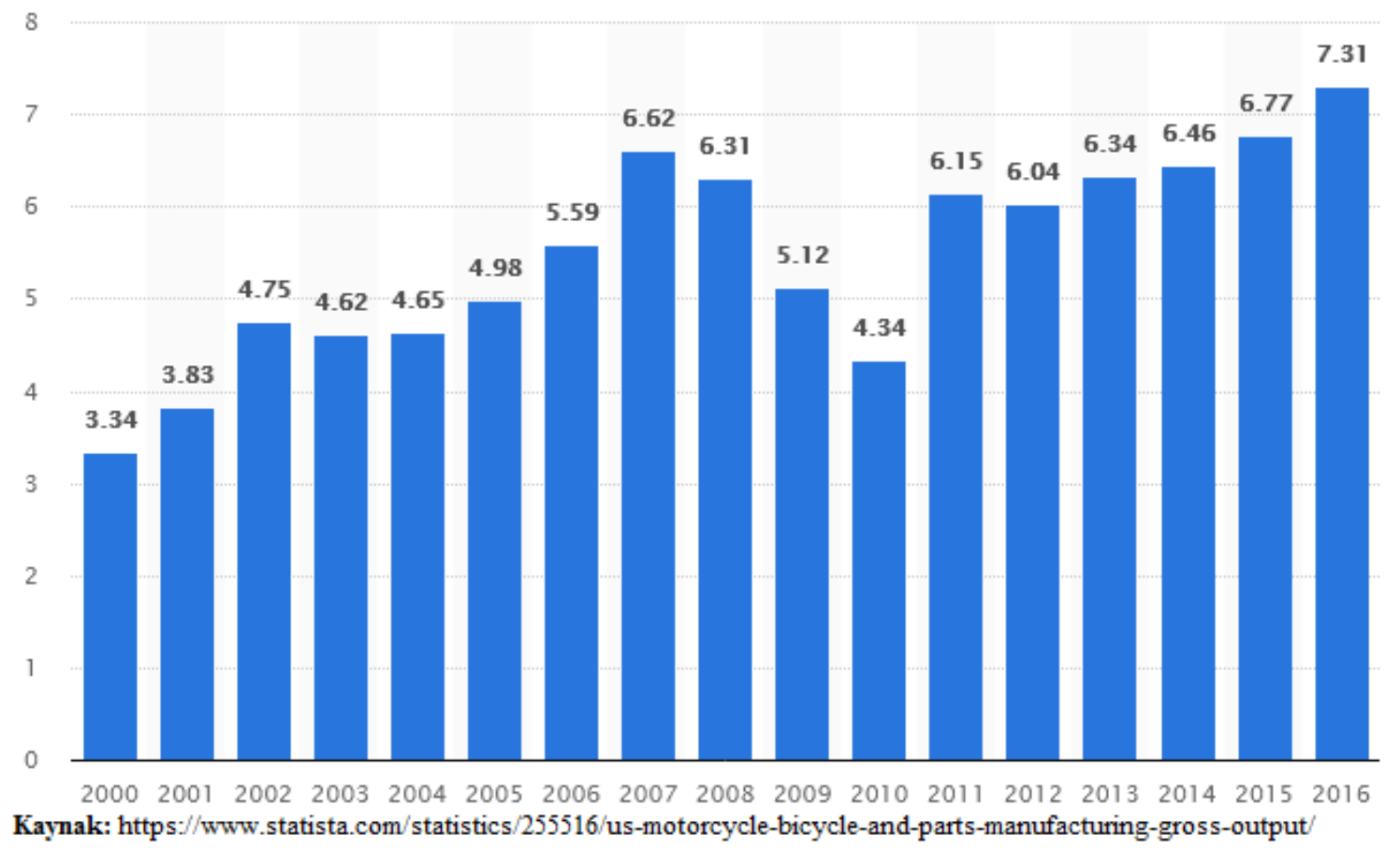

Rekreasyonel boyutuyla bakıldığında diğer rekreasyonel etkinliklerde olduğu gibi motor kullanımının da demografik değişkenlerle ilişkisi vardır. Diğer birçok açık alan rekreasyon aktivitelerinde olduğu gibi erkek egemen yap1 (Ibrahim ve Cordes, 2000) motorun hem rekreasyonel hem de ulaşım ve ticari amaçlı kullanım için de geçerlidir (Christmas ve ark. 2009). Dünya genelinde Çin, Tayvan, Singapur gibi aşırı nüfusa sahip ülkelerde cinsiyet egemenliğindeki makas diğer ülkelere oranla kapanmış durumdadır (Chang ve Lai, 2015).

\footnotetext{
10 - https://www.statista.com/statistics/183549/us-sales-of-motorcycles-since-1990/

11 - https://www.statista.com/statistics/255516/us-motorcycle-bicycle-and-parts-manufacturing-gross-output/ Year 4/ 2020, Volume-4, Issue-3 | WWW.ispecjournal.org
} 
Duprey (2017) yılında yaptığı çalışmada ABD’deki motor kullanıcılarının 1990'da \%6, 2009'da \%10 iken 2017 yılında \%14'ü kadındır. Gabriëlle Stephanie'in (2013) belirttiği sonuçlara göre motosiklet literatürüne bakıldığında özellikle 1935-2007 arasında macera amaçlı uzun sürüşleri (Adventure Based Motorcycle User) kitaplaştıran toplam yedi kişiden ikisi kadındır. Bu kadınların motor kullanımında erkeklerden çok da geride olmadığının, isterlerse yapabilecekleri bir aktivite olduğunun başka göstergesidir.

Evliliğin motor kullanımını olumsuz etkilediğine dair herhangi bir olumsuz bulgu literatürde yoktur. Fakat bekârların ve yaşı genç olanların daha hızlı motor kullandıkları, evlerin ise özellikle ebeveyn olduktan sonra risk algılarının artığı ve çok daha güvenli sürüşü tercih ettikleri, gelir ve sahip olunan motor türü arasında anlamlı bir ilişki olmasa da gelir ile motorun bedeli, yapılan KM arasında önemli bir ilişki olduğu, motor kullanıcılarının önemli bir kısmının iyi eğitim aldığı bulgulanmıştır. Bunun yanında kaza riski en çok olan kullanıcı motor ve yol hâkimiyeti düşük kullanıcılardır. Kaza riskini azaltmanın en önemli yolu bilinçli motor kullanıcisı olmaktır (Watson ve ark. 2007; Christmas ve ark. 2009). Bu durum ABD'de de aynıdır. Duprey'in (2017) çalışmasında yıllar itibariyle (1990'da \%57 iken 2017'de \%61) evli motor kullanıcılarının oranında bir artış olduğu belirtilmekte ve motor kullanıcılarının \%72'si iyi eğitim görmüş bireyler iken, \%71'i bir yerde çalışmakta, \%17'si emekli olduğu ifade edilmektedir.

Türkiye coğrafya ve iklim özellikleri itibariyle motosiklet kullanmaya uygun bir ülkedir. Çin, Tayvan, Singapur gibi ülkeler nüfus yoğunluğu ve trafikteki araç yoğunluğu açısından zorunlu olarak ulaşım amaçlı motor kullanımına yönelse de ülkemiz için motor kullanımı nüfus yoğunluğu ve trafik yoğunluğu yüksek iller dâhil motor kullanımı hala daha çok rekreasyonel nedenledir. Tablo-4'de görüldüğü gibi motorun en yoğun kullanıldığı il İstanbul'dur. Onun dışında en yoğun kullanılan şehirlerin ortak özellikleri Akdeniz ve Ege bölgesinde olmaları, özellikle kışı kısa olan, coğrafik olarak düz yapıdaki şehirlerdir.

Tablo-4: İllere Göre Motorlu Taşıt Sayıları (Ocak 2018 İtibariyle) 


\begin{tabular}{|lrrr|}
\hline il & Toplam & Otomobil & Motosiklet \\
\hline İstanbul & $\mathbf{4 0 8 6 9 0}$ & 2834110 & 292468 \\
Antalya & $\mathbf{1 0 2 5 0 7 3}$ & 480020 & 270089 \\
İzmir & $\mathbf{1 3 5 4 9 7 4}$ & 743572 & 246452 \\
Manisa & $\mathbf{5 7 6} 090$ & 214434 & 174245 \\
Muğla & $\mathbf{4 7 9 3 5 4}$ & 201687 & 151442 \\
Hatay & $\mathbf{4 7 5} \mathbf{9 3 4}$ & 204267 & 149845 \\
Mersin & $\mathbf{5 9 4 0 3 1}$ & 266561 & 144127 \\
Aydın & $\mathbf{4 3 6} \mathbf{0 6 1}$ & 178682 & 122268 \\
Gaziantep & $\mathbf{4 9 2} \mathbf{2 9 8}$ & 222853 & 114819 \\
Balıkesir & $\mathbf{4 6 5 7 8 5}$ & 202966 & 110564 \\
Konya & $\mathbf{7 1 1 4 6 1}$ & 348033 & 103511 \\
Bursa & $\mathbf{8 4 8} 645$ & 476328 & 93365 \\
Denizli & $\mathbf{3 9 6 3 3 9}$ & 191700 & 68923 \\
Şanlıurfa & $\mathbf{2 5 7} \mathbf{4 9 6}$ & 96252 & 65649 \\
Çanakkale & $\mathbf{2 2 3 3 0 2}$ & 90046 & 56909 \\
Ankara & $\mathbf{1 8 9 3 6 7}$ & 1383527 & 46149 \\
Afyonkarahisar & $\mathbf{2 1 7 9 3 9}$ & 87371 & 38467 \\
Isparta & $\mathbf{1 7 2 ~ 3 0 1}$ & 79920 & 36792 \\
Samsun & $\mathbf{3 4 2 0 0 9}$ & 164399 & 35557 \\
\hline
\end{tabular}

Not: Toplama tüm motorlu kara taşıtları dâhildir

Kaynak: TUIK (2018c)

\section{Yöntem}

Araştırmanın amacı; Türkiye'deki Rekreasyonel amaçlı motor kullanıcılarının profillerini belirlemektir.

Araştırma tanımlayıcı bir araştırmadır. Türkiye'de motor kullanıcılarının sayısını doğru bir şekilde belirlenememektedir. $\mathrm{Bu}$ sebeple örneklem olabildiğince büyük tutulmuştur. Örneklem tüm Türkiye genelinden 947 kişiden oluşmaktadır.

Veri toplama aracı olarak araştırmaya özel olarak geliştirilen anket formu kullanılmış ve veriler sosyal medya üzerinden 1 Şubat 2017 - 30 Haziran 2017 tarihleri arasında motor gruplarında uygulanan elektronik anket aracılığıyla toplanmıştır. Çalışmada verilerin sınıflanması ve yorumlanmasında tanımlayıcı istatistikler kullanılmıştır.

\section{Bulgular}

Motor kullanıcılarının demografik özellikleri Tablo-5'de verilmiştir. Tablodan da görülebileceği gibi motor kullanıcılarının neredeyse önemli bir kesimi erkek ve birçoğu üniversite ve üstü eğitim almış iyi eğitim görmüş bireylerdir. Buna ilave olarak evli ve bekâr 
kullanıcıların oranı evlilerin lehine fazla ise de aralarındaki fark çok fazla değildir. Önemli bir çoğunluk özel sektör veya kamuda çalışmakta (\%65.70), 4000 TL ve altı gelire sahip (\%65.50) ve 35-54 yaş aralığındadır (\%48.30). Motor kullanmaya daha çok kendi kararlarıyla başlamaktalar. Ama buna ilave olarak sosyal yaşamdaki arkadaşlarının ve aile bireylerinin etkisi de vardır. Motor etkinliklerine daha çok motor kullanan arkadaşlarıyla, yalnız ve kulüp/dernek gibi organize olmuş ekiple gitmektedirler.

Tablo-5: Motor Kullanıcılarının Demografik Özellikleri

\begin{tabular}{|c|c|c|c|c|c|}
\hline \multirow{2}{*}{ Demografik Değişkenler } & \multirow[b]{2}{*}{$\mathrm{n}$} & \multirow[b]{2}{*}{$\%$} & \multicolumn{2}{|l|}{ Şuan Kullandığı } & \multirow[b]{2}{*}{$\%$} \\
\hline & & & Motor Türü & $\mathrm{n}$ & \\
\hline Erkek & 906 & 95.60 & Enduro & 285 & 30.10 \\
\hline Kadın & 41 & 4.30 & Scooter & 213 & 22.50 \\
\hline Evli & 536 & 56.60 & Turing / Sport Touring & 159 & 16.80 \\
\hline Bekar & 411 & 43.60 & Naked & 120 & 12.70 \\
\hline İlköğretim & 43 & 4.50 & Chopper & 90 & 9.50 \\
\hline Lise ve Dengi & 214 & 22.60 & Super Sport (Racing) & 80 & 8.40 \\
\hline Üniversite ve Üstü & 690 & 72.90 & Motor Kullanmaya Nasıl Başladınız & $\mathrm{n}$ & $\%$ \\
\hline 2000 TL ve alt 1 & 235 & 24.80 & Kendi kişisel kararım & 581 & 61.40 \\
\hline $2001-4000 \mathrm{TL}$ & 385 & 40.70 & Sosyal yaşamdaki arkadaşlarımın etkisi & 205 & 21.60 \\
\hline $4001-6000 \mathrm{TL}$ & 172 & 18.20 & Aile bireylerinin Etkisi & 173 & 18.30 \\
\hline 6001 TL ve üstü & 155 & 16.40 & İş/Okul arkadaşlarımın etkisi & 123 & 13.00 \\
\hline 24 Yaş ve Altı & 103 & 10.90 & Motor etkinliklerinin çekiciliği & 76 & 8.00 \\
\hline 25-34 Yaş & 326 & 34.40 & Medyadaki paylaşımların etkisi & 49 & 5.20 \\
\hline 35-44 Yaş & 292 & 30.80 & Motor Etkinliklerine Kimle Gidiyor & $\mathrm{n}$ & $\%$ \\
\hline 45-54 Yaş & 166 & 17.50 & Motor Kullanan Arkadaşlarla & 529 & 55.90 \\
\hline 55 Yaş ve Üstü & 60 & 6.30 & Yalniz & 360 & 38.00 \\
\hline Özel Sektör & 459 & 48.50 & Kulüp/Dernek Gibi Organize Bir Grupla & 358 & 37.80 \\
\hline Kamu Sektörü & 163 & 17.20 & Eşim/Kız/Erkek Arkadaşımla & 273 & 28.80 \\
\hline Kendi İşim & 203 & 21.40 & Facebookta Organize Olmuş Bir Grupla & 213 & 22.50 \\
\hline
\end{tabular}




\begin{tabular}{lcclcc} 
Öğrenci & 59 & 6.20 & Sosyal Yaşamdaki Arkadaşlarla & 187 & 19.70 \\
Emekli & 63 & 6.70 & Aile Bireyleri & 81 & 8.60 \\
\hline Toplam & 947 & 100.00 & Toplam & 947 & 100.00 \\
\hline
\end{tabular}

Motor kullanıcılarının serbest zamanlarında yaptıkları kültürel, sanatsal, sportif ve diğer aktiviteler Tablo-6'da verilmiştir. Tablodan da görülebileceği gibi motor kullanıcılarının kültürel ve sanatsal aktiviteler açısından bakıldığında daha çok internette gezinmek, evde dinlenmek, sinemaya gitmek, aile ile beraber olmak ve sosyal medyada olmak gibi pasif katılımlı aktiviteleri ve pasif olmayı tercih ederlerken, aktif katılımlı sportif aktivitelerde ise yüksek olmayan bir katılımla daha çok doğa sporları, motor sporları ve fitness merkezlerinde yapılan spor etkinliklerine katılmayı tercih etmektedirler.

Motor kullanıcıları her ne kadar sinemaya gitmek (28 hafta önce), kitap okumak (30 hafta önce) gibi faaliyetleri yapıyorum dese de bu faaliyetleri yapma sıklıkları oldukça düşüktür. Buna ilave olarak, ayda ortalama 40 saat başkalarıyla Facebook, Twiter, yüz yüze veya telefonda motor hakkında konuşmakta ve kritik yapmakta, haftada ortalama 11 saat TV izlemektedir. TV de daha çok Haber ve Belgesel gibi programları izlemekte ve sinema izlemektedirler. Motor kullanıcılarının ailelerindeki diğer motor kullanıcıları açısından bakıldığında oran çok olmasa da daha çok kardeşlerin, babaların ve eşlerin kullanıcı oldukları gözükmektedir.

\section{Tablo-6: Motor Kullanıcılarının Serbest Zamanlarınızda Yaptıkları Aktiviteler}

\begin{tabular}{|c|c|c|c|c|c|}
\hline \multicolumn{3}{|c|}{ Kültürel, Sanatsal ve diğer } & \multicolumn{3}{|l|}{ Sportif } \\
\hline Aktiviteler & $\mathbf{n}$ & $\%$ & Aktiviteler & $\mathbf{n}$ & $\%$ \\
\hline Internette gezinmek & 586 & 61.90 & Doğa Sporları & 352 & 37.20 \\
\hline Evde dinlenmek & 559 & 59.00 & Motor Sporlar1 & 334 & 35.30 \\
\hline Sinemaya gitmek & 448 & 47.30 & Fitness Merkezlerinde Yapılan Sporlar & 299 & 31.60 \\
\hline Aile ile birlikte olmak & 391 & 41.30 & Su Sporları & 277 & 29.30 \\
\hline Sosyal Medyada olmak & 387 & 40.90 & Ferdi Sporlar & 252 & 26.60 \\
\hline Fotoğrafçılıkla ilgilenmek & 232 & 24.50 & Takım Sporları & 195 & 20.60 \\
\hline TV izlemek & 222 & 23.40 & Raket Sporları & 92 & 9.70 \\
\hline Alış verişe çıkmak & 221 & 23.30 & Mücadele Sporları & 63 & 6.70 \\
\hline Müzikle uğraşmak & 215 & 22.70 & Parklardaki rekreatif spor aktiviteleri & 50 & 5.30 \\
\hline Tiyatroya gitmek & 163 & 17.20 & Hava Sporları & 38 & 4.00 \\
\hline El sanatlarıyla uğraşmak & 146 & 15.40 & Halk oyunları ve danslar & 35 & 3.70 \\
\hline
\end{tabular}




\begin{tabular}{|c|c|c|c|c|c|}
\hline TV de izlenen programlar & $\mathbf{n}$ & $\%$ & Ailedeki Diğer Motor Kullanıcıları & $\mathbf{n}$ & $\%$ \\
\hline$\overline{\text { Belgesel }}$ & 691 & 73.00 & Kardeş & 126 & 37.06 \\
\hline Haber & 596 & 62.90 & Baba & 79 & 23.24 \\
\hline Sinema & 472 & 49.80 & Eşim & 44 & 12.94 \\
\hline Spor & 291 & 30.70 & Kuzen/Yeğen & 38 & 11.18 \\
\hline Açık oturum - Tartışma & 279 & 29.50 & Oğlum & 33 & 9.71 \\
\hline Dizi & 271 & 28.60 & Dayı/Amca & 11 & 3.24 \\
\hline Yarışma & 211 & 22.30 & Kızım & 9 & 2.65 \\
\hline Kültür - Sanat & 205 & 21.60 & Toplam & 350 & 100.00 \\
\hline Müzik & 198 & 20.90 & & & \\
\hline Magazin - Eğlence & 87 & 9.20 & & & \\
\hline \multicolumn{4}{|c|}{ Motor Kullanıcılarının Bazı Eylemleri Yapma Sıklıkları } & \multicolumn{2}{|c|}{ Ort \pm St.Spm } \\
\hline \multicolumn{4}{|c|}{ En Son Kaç hafta önce Kitap okudunuz } & \multicolumn{2}{|c|}{$29.46 \pm 76.14$} \\
\hline \multicolumn{4}{|c|}{ En Son Kaç hafta önce Sinemaya Gittiniz } & \multicolumn{2}{|c|}{$27.78 \pm 76.68$} \\
\hline \multicolumn{4}{|l|}{ Haftalık TV izleme süreniz } & \multicolumn{2}{|c|}{$10.91 \pm 14.88$} \\
\hline \multicolumn{4}{|c|}{ Motosikleti konuşmak, kritik yapmak için ayda harcanan süre (saat) } & \multicolumn{2}{|c|}{$40.50 \pm 66.01$} \\
\hline
\end{tabular}

Motor kullanıcılarının eğitim ihtiyaçları ve donanım bilgileri Tablo-7'de verilmiştir. Tablodan da görülebileceği gibi motor kullanıcılarının yarısı (\%50.70) ileri sürüş eğitimi almadığını, önemli bir kısmının (\%77.70) ileri sürüş eğitimine ihtiyacı olduğunu, yeteri düzeyde ilk yardım ve arama kurtarma bilgisine sahip olmadığını (\%67.40) ve arama-kurtarma eğitimi almak istediğini (\%59.10) belirtmişlerdir. Bunun yanında motorcuların önemli bir kısmı GPS (\%67.90), Navigasyon cihazı (\%54.70) ve sürüş anında ekipteki diğer motorcularla iletişmek için telsiz veya Bluetoot (\%66.10) kullanmadıklarını belirtmişlerdir. Motor kullanıcılarının önemli bir kısmı (\%97.30) sosyal medyadaki motor gruplarından en az birine üye olduğunu, motorla ilgili yayınları düzenli takip etmediğini (\%64.80) ve yılda en az bir kere motor festivallerinden birine (\%65.20) katılmaktadırlar.

Motor aynı zamanda güvenlik düzeyi yüksek ekipmanın varlığını ve kullanımını gerektirir. Kullanıcıların önemli kısmı yazlık özel kıyafet (\%69.00), kışlık özel kıyafet (\%79.40), eldiven (\%94.30), güvenlik sınıfına uygun kask (\%91.90), motosiklet montu (\%92.90), motosiklet pantolonu (\%59.30) ve motosiklet botunda (\%54.00) güvenlik sinıfina ve mevsimine uygun kıyafet kullanırken hem gece hem de gündüz sürüşlerde fark edilmeyi sağlayan reflektörlü yeleği (\%54.80) kullanmamaktadırlar.

Bunlara ilave olarak motor kullanıcıları kendilerinin bilinçli motor kullanıcısı olduğunu düşünürken, etraflarında bilinçsiz şekilde motor kullanan birçoklarının olduğunu ve trafikteki 
tüm sürücülerin hem motor kullanıcılarına hem de bisiklet kullanıcılarına saygılı olmaları için bir eğitimden geçirilmesi gerektiğine inanmaktadırlar.

\section{Tablo-7: Motor Kullanıcılarının Eğitim ihtiyaçları ve Donanım Bilgileri}

\begin{tabular}{|c|c|c|c|c|}
\hline \multirow{2}{*}{$\begin{array}{l}\text { Eğitim ihtiyaçları ve } \\
\text { Donanım bilgileri }\end{array}$} & \multicolumn{2}{|l|}{ Evet } & \multicolumn{2}{|c|}{ Hayır } \\
\hline & $\bar{n}$ & $\%$ & $\mathbf{n}$ & $\%$ \\
\hline İleri Sürüş Teknikleri Eğitimi Aldınız mı? & 467 & 49.30 & 480 & 50.70 \\
\hline İleri Sürüş Teknikleri Eğitimine İhtiyacınız Olduğunu Düşünüyor musunuz? & 736 & 77.70 & 211 & 22.30 \\
\hline İlk Yardım Eğitimi Almak İsterim & 657 & 69.40 & 290 & 30.60 \\
\hline Arama-Kurtarma Eğitimi Almak İsterim & 560 & 59.10 & 387 & 40.90 \\
\hline Yeteri Düzeyde İlk Yardım-Arama ve Kurtarma Bilgilerine Sahip misiniz? & 309 & 32.60 & 638 & 67.40 \\
\hline GPS Cihazı kullanıyor musunuz? & 304 & 32.10 & 643 & 67.90 \\
\hline Navigasyon Cihazı kullanıyor musunuz? & 429 & 45.30 & 518 & 54.70 \\
\hline Sürüşte Motorcularla İletişim için Telsiz Bluetoot kullanıyor musunuz? & 321 & 33.90 & 626 & 66.10 \\
\hline Facebookta Herhangi Bir Motor Grubuna Üye misiniz? & 921 & 97.30 & 26 & 2.70 \\
\hline Y1lda bir Motor Festivallerinden Birine Katılır mısınız? & 617 & 65.20 & 330 & 34.80 \\
\hline Motor İle İlgili Yayınları Düzenli Takip Ediyor musunuz? & 333 & 35.20 & 614 & 64.80 \\
\hline Şehir Trafiğinde Motor Kullanıcılarına Saygılı Davranılmaktadır & 45 & 4.80 & 902 & 95.20 \\
\hline Şehirler Arası Yollarda Motor Kullanıcılarına Saygılı Davranılmaktadır & 88 & 9.30 & 859 & 90.70 \\
\hline Yazlık Özel Kıyafet & 653 & 69.00 & 294 & 31.00 \\
\hline Kışlık Özel Kıyafet & 752 & 79.40 & 195 & 20.60 \\
\hline Reflektörlü Yelek & 428 & 45.20 & 519 & 54.80 \\
\hline Eldiven & 893 & 94.30 & 54 & 5.70 \\
\hline Güvenlik Sınıfına Uygun Kask & 870 & 91.90 & 77 & 8.10 \\
\hline Motosiklet Montu & 878 & 92.70 & 69 & 7.30 \\
\hline Motosiklet Pantolonu & 562 & 59.30 & 385 & 40.70 \\
\hline Motosiklet Botu & 511 & 54.00 & 436 & 46.00 \\
\hline Özellik & & & Ort $\pm S$ & Spm \\
\hline Diğer Sürücüler motora saygılı olmaları için mutlaka bir eğitimden geçirilmelidir* & & & $4.60 \pm$ & \\
\hline Bilinçli bir motor kullanıcısı olduğumu düşünüyorum* & & & $4.37 \pm 0$ & \\
\hline Etrafımda bilinçsiz şekilde motor kullanan birçok kişi var* & & & $4.18 \pm 1$ & \\
\hline
\end{tabular}

*1- Kesinlikle Katılmıyorum ... 5-Kesinlikle Katılıyorum arasında ölçeklenmiştir

Motor kullanıcılarının kasklarının güvenli olması önemlidir. Güvenlik derecesi Uluslararası standartlarla (SHARP The Helmet Safety Scheme) belirlenmektedir. Her kask üreticisi ürettiği kasklara bu standartlara uygun olarak güvenlik sınıfına uygun bir güvenlik derecesi verir. Buna göre motor kullanıcılarının kasklarının güvenlik derecelerine uygunluğu Tablo- 
8'de verilmiştir. Buna göre yüksek güvenlikli kaska sahip kullanıcılarının oranı (\%78.30) oldukça yüksektir.

Tablo-8: Motor Kullanıcılarının Kasklarının Güvenlik Derecesi

\begin{tabular}{lll}
\hline Kullandığınız Kaskın Güvenlik Derecesi & $\mathbf{n}$ & $\mathbf{\%}$ \\
\hline Zayıf & 20 & 2.10 \\
Orta & 186 & 19.60 \\
İyi & 387 & 40.90 \\
Çok İyi & 354 & 37.40 \\
\hline Toplam & $\mathbf{9 4 7}$ & $\mathbf{1 0 0 . 0 0}$ \\
\hline
\end{tabular}

Motor kullanıcılarının harcamaları Tablo-9'da verilmiştir. Tablodan da görülebileceği gibi motor kullanıcıları aylık ortalama yakıt masrafları 241 TL (2892 TL yıllık), yıllık tamir bakım masrafları $683 \mathrm{TL}$, yıllık yedek parça masrafi $564 \mathrm{TL}$, etkinliklerde ortalama aylık kişisel harcaması 262 TL, yıllık sigorta vergi bedeli 263 TL ve y1llık sigorta bedeli 521 TL'dir. Motor kullanıcılarının beyan ettikleri yıllık ortalama giderleri 5184 TL'dir. Diğer bir deyişle ortalama aylık kazançlarının 3000 TL yaklaşık \%15 inin motor kullanımına harcandığını göstermektedir. Bu veriler esas alındığında motorcuların aylık yaklaşık 432.06 TL aylık harcamasi vardır.

Tablo-9: Motor Kullanıcılarının Ekonomiye Katkıları

\begin{tabular}{llll}
\hline Masraflar & Min & Max & Ort \pm St.Spm \\
\hline Aylık Yakıt Masrafı (TL) & 10 & 1.500 & $241.02 \pm 182.99$ \\
Yıllık Tamir/Bakım Masrafı (TL) & 0 & 5.000 & $682.95 \pm 712.76$ \\
Yıllık Yedek Parça Masrafı (TL) & 20 & 5.000 & $563.09 \pm 590.49$ \\
Etkinliklerdeki Kişisel Harcamalar (aylık - TL) & 20 & 3.000 & $261.80 \pm 429.07$ \\
Yıllık Vergi (TL) & 0 & 6.000 & $263.23 \pm 317.54$ \\
Yıllık Sigorta Bedeli (TL) & 0 & 18.000 & $521.41 \pm 768.10$ \\
\hline Motor Kullanıcılarının Aylık Ortalama Harcamaları & & & $\mathbf{4 3 2 . 0 6}$ TL
\end{tabular}

Motor kullanıcılarının profil çalışmasına katılanların yaşadıkları iller Tablo-10'da verilmiştir. Tablodan da görülebileceği gibi ankete katılımda İstanbul (\%31.40) birinci sırada, Antalya (\%21.40) ikinci sırada ve İzmir (\%11.40) üçüncü sıradadır.

Tablo-10: Ankete Katılan Motorcuların Yaşadıkları İller Year 4/ 2020, Volume-4, Issue-3 | WWW.ispecjournal.org 


\begin{tabular}{lll}
\hline Anketine Katılanların Yaşadıkları İller & $\mathbf{n}$ & $\mathbf{\%}$ \\
\hline İstanbul & 297 & 31.40 \\
Antalya & 203 & 21.40 \\
İzmir & 108 & 11.40 \\
Ankara & 60 & 6.30 \\
Bursa & 54 & 5.70 \\
Eskişehir & 21 & 2.20 \\
Muğla & 20 & 2.10 \\
Manisa & 18 & 1.90 \\
Çanakkale & 15 & 1.60 \\
İçel & 15 & 1.60 \\
Balıkesir & 14 & 1.50 \\
Aydın & 11 & 1.20 \\
Isparta & 11 & 1.20 \\
Burdur & 10 & 1.10 \\
Diğer İller & 90 & 9.50 \\
\hline
\end{tabular}

Bireylerin motor kullanma nedenleri Tablo-11'de verilmiştir. Tablodan da görülebileceği gibi bireylerin motor kullanma nedenleri öncelik sırasıyla ilk onu "Özgürlük hissi verdiği için", "Motor kullandığımda yenilenmiş ve tazelenmiş hissettiğim için", "Motorun cazibesi beni heyecanlandırdığı için", "Günlük rutinden uzaklaşmak için", "Kalabalıktan ve stresten uzaklaşmak için”, “Güç ve hareketle doğayı keşfedebildiğim için”, "Doğada Olabilmek ve/veya İstediğim bir yere gidebilmek İçin”, "Sakinlik ve sessizlik bulduğum için”, "Güç ve hareketi deneyimlediğim için" ve "Yeni bir güç ve enerji elde ettiğim için"dir. Bireyi motor kullanmaya motive eden nedenlerin önem derecesi en az olan beşi öncelik sırasıyla "Ailemle birlikte olabildiğim için", "Sosyal güç elde etmek için”, "Okul/İş arkadaşlarımla beraber olabildiğim için", "Yaşadığım yerdeki tanıdıklarımla birlikte olabildiğim için" ve "Aile bireylerine örnek olmak için"dir.

Tablo-11: Bireylerin Motor Kullanma Nedenleri 
Özgürlük hissi verdiği için

Motor kullandığımda yenilenmiş ve tazelenmiş hissettiğim için

Motorun cazibesi beni heyecanlandırdığı için

Günlük rutinden uzaklaşmak için

Kalabalıktan ve stresten uzaklaşmak için

Güç ve hareketle doğayı keşfedebildiğim için

Doğada Olabilmek ve/veya İstediğim bir yere gidebilmek İçin

Sakinlik ve sessizlik bulduğum için

Güç ve hareketi deneyimlediğim için

Yeni bir güç ve enerji elde ettiğim için

Bedenimi ve ruhumu geliştirerek, rehabilite edebildiğim için

Kendini geliştirmek ve yeni beceriler edinmek istediğim için

Dinlenme istediğim için

Riskle mücadele edebileceğim için

Ağır ve zor koşullarla başa çıkmayı istediğim için

Mücadele ruhunu geliştirdiği için

Aynı şeyleri yapmaktan keyif alan başkalarıyla birlikte olabilmek için

Kendimi gerçekleştirmek için

Değişik beceriler gerektiren outdoor aktiviteleri yapabilme becerisi kazandığım için

Kendimle rekabet edebildiğim için

Toplumdaki bireylere örnek olmak için

Kullandığım ekipmanların gücü deneyimlememe olanak tanıdığı için

Sosyal ilişki kurmak, yeni insanlarla tanışmak veya onları gözlemek için

Fiziksel aktivite yapmak istediğim için

Sosyal dünyadan arkadaşlarımla birlikte olabildiğim için

Çevremdeki bireylere örnek olmak için

Başarı arzuladığım için

Motor kullanmak kronik birçok hastalıktan koruduğu için 
Motor kullanmak bir grubun parçası olmamı sağladığı için

$2.91 \quad 1.36$

Egzersiz ve antrenman yapmak için

$2.87 \quad 1.28$

Partnerimle (Kız veya Erkek Arkadaş) olabildiğim için

$2.82 \quad 1.47$

Başkalarına Motor Kullanıyorum demek beni mutlu ettiği için

$2.82 \quad 1.45$

Takdir edildiğim ve dikkat çektiğim için

$2.78 \quad 1.41$

Aile bireylerine örnek olmak için

$2.70 \quad 1.47$

Yaşadığım yerdeki tanıdıklarımla birlikte olabildiğim için

$2.51 \quad 1.34$

Okul/İş arkadaşlarımla beraber olabildiğim için

$2.49 \quad 1.35$

Sosyal güç elde etmek için

$2.34 \quad 1.26$

Ailemle birlikte olabildiğim için

$2.16 \quad 1.35$

Motor türüne göre motor kullanan bireylerin motor etkinliklerine kimlerle gittiklerine göre dağılımı Tablo-12'de verilmiştir. Tablodan da görülebileceği; Chopper kullanan motorcular motor etkinliklerine daha çok motor kullanan arkadaşlarıyla (\%29.57) ve Kulüp veya Dernek altında organize olmuş grupla (\%18.82) gitmektedirler. Enduro kullanan motorcular ise motor etkinliklerine daha çok motor kullanan arkadaşlarıyla (\%25.00) ve yalnız (\%21.22) gitmektedirler. Naked kullanan motorcular motor etkinliklerine daha çok motor kullanan arkadaşlarıyla (\%26.02) ve yalnız (\%19.51) gitmektedirler. Scooter kullanan motorcular motor etkinliklerine daha çok motor kullanan arkadaşlarıyla (\%25.98) ve Kulüp veya Dernek altında organize olmuş grupla (\%19.87) gitmektedirler. Turing/Sport Turing kullanan motorcular motor etkinliklerine daha çok motor kullanan arkadaşlarıyla (\%27.60) ve yalnız (\%18.10) gitmektedirler. Super Sport (Racing) kullanan motorcular motor etkinliklerine daha çok motor kullanan arkadaşlarıyla (\%27.71) ve yalnız (\%16.87) gitmektedirler.

Tablo-12: Motor Etkinliklerine Kimle Gittiği Gitme ve Motor Türü Frekans Değerler Year 4/ 2020, Volume-4, Issue-3 | WWW.ispecjournal.org 


\begin{tabular}{|c|c|c|c|c|c|c|c|}
\hline \multirow{2}{*}{\multicolumn{2}{|c|}{ Motor Etkinliklerine Kimlerle Gidiyor }} & \multirow[b]{2}{*}{ Chopper } & \multirow[b]{2}{*}{ Enduro } & \multirow[b]{2}{*}{ Naked } & \multirow[b]{2}{*}{ Scooter } & \multirow{2}{*}{$\begin{array}{l}\text { Turing/ } \\
\text { Sport } \\
\text { Touring }\end{array}$} & \multirow{2}{*}{$\begin{array}{l}\text { Super } \\
\text { Sport } \\
\text { (Racing) }\end{array}$} \\
\hline & & & & & & & \\
\hline Motor Kullanan & $\mathbf{n}$ & 55 & 152 & 64 & 119 & 93 & 46 \\
\hline Arkadaşlarla & $\%$ & 29.57 & 25.00 & 26.02 & 25.98 & 27.60 & 27.71 \\
\hline Yalnız & $\mathbf{n}$ & 27 & 129 & 48 & 67 & 61 & 28 \\
\hline Gidiyorum & $\%$ & 14.52 & 21.22 & 19.51 & 14.63 & 18.10 & 16.87 \\
\hline $\begin{array}{llll}\text { Kulüp } & \text { veya } & \text { Dernek } & \text { Alt }\end{array}$ & Itından & 35 & 108 & 38 & 91 & 59 & 27 \\
\hline Organize Olmuş Bir Grupla & $\%$ & 18.82 & 17.76 & 15.45 & 19.87 & 17.51 & 16.27 \\
\hline Eşim/Kız/Erkek & $\mathbf{n}$ & 28 & 73 & 29 & 65 & 49 & 29 \\
\hline Arkadaşımla & $\%$ & 15.05 & 12.01 & 11.79 & 14.19 & 14.54 & 17.47 \\
\hline Facebookta Organize Olmuş & Birn & 17 & 65 & 30 & 55 & 34 & 12 \\
\hline Grupla & $\%$ & 9.14 & 10.69 & 12.20 & 12.01 & 10.09 & 7.23 \\
\hline Sosyal Yaşamdaki & $\mathbf{n}$ & 18 & 60 & 28 & 39 & 27 & 15 \\
\hline Arkadaşlarla & $\%$ & 9.68 & 9.87 & 11.38 & 8.52 & 8.01 & 9.04 \\
\hline$\overline{\text { Aile }}$ & $\mathbf{n}$ & 6 & 21 & 9 & 22 & 14 & 9 \\
\hline Bireyleriyle & $\%$ & 3.23 & 3.45 & 3.66 & 4.80 & 4.15 & 5.42 \\
\hline \multirow[t]{2}{*}{ Toplam } & $\mathbf{n}$ & 186 & 608 & 246 & 458 & 337 & 166 \\
\hline & $\%$ & 100.00 & 100.00 & 100.00 & 100.00 & 100.00 & 100.00 \\
\hline
\end{tabular}

\section{Tartışma}

Bireylerin motor kullanmaya motive eden nedenlere bakıldığında motor kullanımının ne kadar cazip bir açık alan rekreasyonu ve serbest zaman etkinliği olduğu görülmektedir. Önceliklere bakıldığında; özgürlük hissi vermesi, yenilenmiş tazelenmiş hissettirmesi, motorun cazibesinin kullanıcıları heyecanlandırması, günlük rutinden, kalabalıktan ve stresten uzaklaştırması, doğayı keşfetme fırsatı vermesi, istediği yere gidebilme firsatı vermesi, sakinlik ve sessizlik sunması, bedeni ve ruhu geliştirmesi açık alan rekreasyon talebini etkileyen faktörlerle büyük ölçüde aynılık göstermektedir (Ardahan ve ark. 2016; Ardahan ve Mert, 2014; İbrahim ve Cordes, 2002).

Bireylerin motor kullanma nedenlerinin son sıralarında yer alan maddelere bakıldığında bireylerin motor etkinliklerine kimlerle gitmedikleri büyük ölçüde birbirlerini doğrulamaktadırlar. Bireylerin çok az bir kısmı aile bireyleri ve sosyal yaşamdaki arkadaşlarıyla motor etkinliklerine gittiklerini belirtmişlerdir ve bu durum; motor kullanma nedenlerinin son sıralarında yer alan maddelerden "Ailemle birlikte olabildiğim için”, "Sosyal güç elde etmek için”, “Okul/İş arkadaşlarımla birlikte olmak için” ve "Yaşadığım yerdeki 
tanıdıklarımla birlikte olduğum için" maddeleriyle karşılıklı birbirlerini desteklemektedirler. Sosyalleşmek her ne kadar bireyleri motor kullanmaya motive eden faktörler sıralamasında ilk önceliği alsa da (Ardahan, ve Güleç, 2017) sosyalleşme daha çok motor kullanıcılarıyla kendi aralarında yaratacakları Motorcularla Sosyalleşme ve motor kullanmak ve motorun keyfini çıkarmaktır. Bunun yanında Uzaklaşmak ve Dinlenmek, Motorun gücünü deneyimleme, Fiziksel aktivite sağlık, Kendini yenileme ve gelişme, Kişinin kendiyle olan rekabeti, Örnek olma ve Tanınma arzusu motor kullanımının ana nedenleridir.

Ulaşım amaçı motor kullanımında kadınlar ve erkeklerin arasındaki makasın kapandığı birçok ülkede bulgulansa da (Chang ve Lai, 2015), diğer birçok açık alan rekreasyonu faaliyetinde özellikle güce dayalı aktivitelerde rekreasyonel motor kullanımının da erkeklerin egemenliğindedir (Duprey, 2017; Harrington ve Dawson, 1995; Jackson ve Henderson, 1995; Ibrahim ve Cordes, 2002). Motor kullanımında bu durum kadınları daha çok motordaki ikinci kişi/yolcu olmaya yöneltmektedir. Bu kadınların motor kullanımındaki yetersizliği ya da beceremeyeceği anlamına gelmemektedir. Bu tamamen toplumdaki cinsiyet algısından, kadın ve erkeklerin yetiştirilme biçiminden, çocukluktan itibaren verilen firsatlardaki eşitsizlikten kaynaklanabilir. Bunun yanında herkesin yapabildiği günübirlik doğa yürüyüşleri, bisiklet, koro gibi faaliyetlerde cinsiyetler arasında katılım üstünlüğü çok belirgin değildir (Ardahan ve Çalışkan, 2017; Ardahan ve Akdeniz, 2017; Ardahan ve Mert, 2014). Medeni durumun motor kullanımını belirlediğine dönük literatürde herhangi bir bilgi olmasa da bekârların ve yaşı genç olanların daha hızlı motor kullandıkları, yaş ilerleyip bireylerin annelik-babalık gibi sosyal rolleri ve profesyonel kariyerleri yükseldikçe risk algılarının arttığı ve çok daha güvenli sürüşü tercih ettikleri birçok çalışmada vurgulanmıştır (Powell, 2017). Buna ilave olarak, gelir ve sahip olunan motor türü arasında bir ilişki olmasa da gelir ile motorun bedeli, yapılan KM arasında önemli bir ilişki olduğu, motor kullanıcılarının önemli bir kısmının iyi eğitim aldığı bulgulanmıştır (Watson ve ark. 2007; Christmas ve ark. 2009). Gelir ilişkisi açısından bakıldığında bireylerin alık kişisel gelirlerinin ortalama \%15'lerini harcıyor olmaları motor kullanımının onların hayatlarındaki önemini de göstermektedir.

Mevcut araştırmada bulgulanan bireylerin motor kullanımına başlamada etkili olan en önemli, en belirleyici nedenlerin başında bireylerin kendi kişisel kararları gelmektedir. Bunları sırasıyla sosyal dünyadaki arkadaşların ve aile bireylerinin etkisi takip etmektedir. Bu sonuçlar motor kullanıcılarının motor kullanmak konusunda mevcut riskleri bilerek, görerek, kabul ederek, bilinçli bir tercih ortaya koyduklarını göstermektedir. Motor kullananların 
ailelerinde kendilerinden başka motor kullanıcılarının başında "Kardeş" ve "Baba" geliyor olsa da oranları çok değildir. Dolayısıyla günümüzde aile etkileşimli motor kullanımının yaygın olmaması da büyük sebeple gerçekleşmemektedir. Ĕger mevcut kullanıcıların kendileri veya en yakınındaki kişiler motor kullanırken telafisi zor olacak deneyim yaşamazlarsa belki de gelecek nesillerde aile etkileşimli motora başlama nedenleri yer alabilecektir.

Motor büyük ölçüde Motor kullanan bireylerle, Kulüp/Dernek gibi organize bir grupla, Yalnız, Eş/Kız-Erkek arkadaşla, Facebook üzerinde örgütlenmiş bir grupla gerçekleştirilen bir serbest zaman aktivitesidir. Hatta motorcular motor türleriyle bile kendi içlerinde ayrı gruplar oluşturmaktadır. Örneğin Chopper kullanıcıları daha çok motor kullanan arkadaşlarıyla -ki muhtemelen burada kastedilen arkadaşlar Chopper kullanıcılarıdır- etkinlik yaparlarken, Enduro tarzı motor kullananlar hem motor kullanan arkadaşlarıyla hem de yalnız etkinlik yapmaktadırlar. Enduro kullanıcıları doğaya giderken, doğanın getirdiği koşullara dayanıklılık açısından mutlaka kendi tarzından motor kullanıcılarıyla gitmek isteyeceklerdir. Scooter tarzı motorlar daha çok ulaşım amaçlı kullanılsalar da Enduro ve Sport Racing’ler gibi özel amaçların dışındaki tüm sürüşleri yapabilme imkanı vereceği için bireyler daha çok motor kullanan arkadaşlarıyla ve kulüp/dernek atında organize olmuş grupla etkinlik yapmayı istemektedirler. Naked tarzı motor kullananlar Chopper kullanıcıları gibi motor kullanan arkadaşlarıyla ve yalnız etkinliklere katılmayı tercih etmektedirler. Sport Racing kullanıcıları motor kullanan arkadaşlarıyla ve eş/kız-erkek arkadaşıyla beraber etkinlik yapmayı tercih etmektedir. Tüm bunların hepsinde ortak olan bireylerin kendi gibi olanlarla beraber oluşturduğu bir gruba aitlik ihtiyacını da gidermektir. Rekreasyonun en temel faydalarından biri de bireylerde aidiyet duygusu yaratması, bireyin kendisini bir gurubun parçası olarak görmesini sağlamasıdır (Ardahan ve ark. 2016; Inrahim ve Cordes, 2002). Birey her ne kadar motor etkinliklerine yalnız katılsa da Motor Kullanıcılığının sağladığı aidiyet, Motor kullanan arkadaşlarıyla oluşturulan gruba aidiyet duygusu, Facebook gibi sosyal medyada da olsa bir grubun, kup veya derneğin parçası olmak bireyde yüksek düzeyde aidiyet duygusu yaratmaktadır. Bu özellikle Chopper kullanıcılarında bir akım olarak yaygındır.

Açık alan rekreasyonu katılımcıları açısından bakıldığında bireylerin rekreasyonel yaşamları ile evlilik yaşamları büyük ölçüde karşılıklı birbirlerini etkilemektedir. Bireyler evli olsalar bile kendileri için özellikli olan rekreasyonel aktivitelere daha çok o etkinliği yapan bireylerle, 
ikinci sırada yalnız, kulüp dernek gibi organize olmuş gruplarla üçüncü sırada da eşleri/kızerkek arkadaşları, sosyal yaşamdan arkadaşları ve aile bireyleriyle katılmayı tercih etmektedirler (Ardahan ve Mert, 2014; Kaplan Kalkan ve Ardahan, 2013; Ardahan ve Akdeniz, 2017; Ardahan ve Çalışkan, 2017). Bu durum motor kullanıcıları için de benzerdir. $\mathrm{Bu}$ açıdan bakıldığında çıkarılabilecek en önemli sonuç, bireylerin evliliklerinin ve eşlerinin hobi dünyalarıyla çok örtüşmese de birbirlerinin hobilerini yapmalarına engel olmadıklarıdır. Elbette bu durumun daha detaylı çalışılıp bu sonuca neden olan etmenlerin belirlenmesi gereğidir.

Motor sahipliği motor bedeli, vergi, sigorta gibi rutin giderler ve elbette yapılan KM ye bağl1 olarak da sürücüsüne maliyet yükleyen, kişisel ve/veya aile gelirinden belirli bir bütçenin kullanılmasını gerektiren rekreasyonel bir etkinliktir. Her ne kadar motor sahibi olmakla gelir arasında bir ilişki olmasa da motorun aktif yaşamda hobi amaçlı kullanımı bireylerin belirli bir gelir düzeyinde olmasını gerektirmektedir. Bu haliyle baktığımızda mevcut araştırmada emekli motor sürücülerinin düşük olması oldukça manidardır. Ülkemizde genel ücret seviyeleri gelişmiş ülkelerle karşılaştırıldığında oldukça düşüktür. Bu durum emekliler için kölelik ücreti düzeyindedir. Emekliler motor kullanımı gibi maliyetli etkinlikler yerine daha düşük katılım ve sürdürme bedeli olan etkinlikleri tercih etmektedir (Ardahan ve Akdeniz, 2017).

Motor kullanıcılarının motor kullanmak dışında çok aktif olmayan bir hayatları vardır. Motorcular gündelik hayatlarının önemli bir kısmını motor hakkında konuşarak, kritik yaparak geçirirlerken, TV de daha çok belgesel, haber, sinema ve spor programlarını izlemektedirler. Çok fazla kitap okumamaktalar, seyrek düzeyde sinemaya gitmektedirler ve az TV izlemektedirler. Bireyler aktif olarak yaptıkları bir hobileri varsa onu destekleyecek ve aktif katılım gerektiren fitness merkezlerinde yapılan sporlar, yüzme gibi etkinliklere dâhil olmak dışında daha çok evde vakit geçiren, internette gezinen, aile ile birlikte zaman harcamayı tercih eden, sosyal medyada zaman harcayan serbest zaman etkinliklerini motor kullanıcılarının hayatlarında ve bisiklet kullanıcıları, avcılar, balıkçılar, dağcılık, doğa sporları gibi açık alan rekreasyonu faaliyetleri yapanlarda da görmekteyiz. (Ardahan ve Mert, 2014; Kaplan Kalkan ve Ardahan, 2013; Ardahan ve Akdeniz, 2017; Ardahan ve Çalışkan, 2017; Ardahan ve Turgut, 2013). 
Mevcut çalışmadaki motor kullanıcılarının motor konusundaki bilinç ve farkındalık düzeylerinin yüksek olduğunu, güvenlik araçlarına sahip olduklarını ve kullandıklarını söylenebilir. Bunda son yıllarda özellikle Facebook dâhil tüm sosyal medyada oluşan motor gurupları, motorcuların kendi aralarında daha çok etkileşimi, yapılan bilinçlendirme çalışmaları, motor ve yol hâkimiyeti kurslarının etkili olduğu söylenebilir. Motorcuların mevsime uygun kıyafet kullanımı, kask, eldiven, mont, pantolon, bot, GPS ve Navigasyon aracı gibi güvenlik ekipmanlarına sahip olmaları ve kullandıklarını belirtmeleri bilinç konusundaki tutarlılığı göstermektedir. Bu tespitleri motor kullanıcılarının yaklaşık \%50 si ileri sürüş teknikleri eğitimi almışken, yaklaşık \%80'inin hala bunu yeterli görmeyip ileri sürüş teknikleri eğitimi almayı istemesi, yaklaşık \%70'inin yeteri düzeyde ilk yardım, arama ve kurtarma eğitimi almadığını beyan etmesi ve bu eksikliği gidermek için, yaklaşık \%70'inin ilk yardım eğitimi, \%60’ının arama kurtarma eğitimi almayı istemesi doğrulamaktadır. Bunun yanında motor ile ilgili yayınları da düzenli olarak takip etmemeleri önemli farkındalığın oluşmasında önemli bir eksikliktir. Okuma eksikliği ile ilgili sonuçlar Avcı ve arkadaşlarının (2010), Arıcı (2008)'in çalışmalarında belirttiği “Okumuyoruz, Okuyan bir toplum değiliz” tespitleriyle örtüşmektedir. Trafikteki araçlar kendilerine saygı duyulmasını istemekteler fakat kendileri başka araçlara saygı göstermemektedirler. Motorcuların önemli bir kısmı şehir içi trafikte ve şehirlerarası yollarda kendilerine saygılı davranılmadığını söylemektedirler. Her ne kadar motor kullanıcıları kendilerini bilinçli motor kullanıcısı olarak görseler de saygının karşılıklılık ilkesi açısından bakıldığında motorcuların da şehir içi ve dışı yollarda yaptıkları sürüşlerde trafik kurallarına uyup/uymadıklarının, trafikteki diğer kişilere saygılı olup olmadıklarının da sorgulanması oldukça önemlidir. Motor kullanıcıları bunu doğrular nitelikte etraflarında birçok bilinçsiz motor kullanıcısının olduğunu belirtmişlerdir.

Farkındalık ve bilinç sağlamanın en önemli adımı belki de motor sürücü ehliyeti almanın zorlaştırılması, gerekli eğitiminin sürüş ve hâkimiyet kazanana kadar sürdürülmesi motor kullanımının temelini teşkil ettirecek alt yapı olduğu için bu beceriyi kazanmayanlara ehliyet verilmemelidir.

Ülkemiz motor kullanımına uygun bir coğrafyaya sahiptir. Özellikle Ege, Akdeniz, Marmara ve İç Anadolu bölgesindeki iller bu konuda yaygınlık göstermektedir. Araştırmaya katılanların şehirlere göre sıralaması büyük ölçüde TUIK' in (2018c) yayınladığı İllere Göre motosiklet sayılarıyla örtüşmektedir. Böylelikle ana kütleye uygun bir örneklem olduğu da doğrulanmış olmaktadır. 
Sonuç olarak; rekreasyonel motor kullanımı serbest zaman tatmini yaratmanın yanında önemli bir ekonomik değer yarattığı, bilinçli yapıldığı sürece kullanıcılarının yaşamlarında ciddi boş zaman faaliyeti olabilecek bir etkinliktir. Dünya genelinde yaygınlaşan motor kullanımında sürüş riskini azaltmak için hem motor kullanıcılarının hem de trafikteki diğer sürücülerin bilinçlendirilmesi, motor ve yol hâkimiyetinin sağlandiğı ileri sürüş tekniklerinin öğretilmesi önemli bir zorunluluk olmalıdır. Hatta bu bağlamda motor sürücü ehliyeti alma zorlaştırılmalıdır.

\section{Kaynaklar}

Ardahan, F. ve Akdeniz, Y. (2017). Koristlerin Profilleri ve Bireyleri Korolara Korist Olarak Katılmaya Motive Eden Faktörlerin Demografik Değişkenlerle Karşılaştırılması: Antalya Örneği. Mehmet Akif Ersoy Üniversitesi, Beden Eğitimi ve Spor Yüksekokulu, Uluslararası 4. Turizm ve Rekreasyon Kongresi, 21-23 Nisan 2017, Burdur, Türkiye.

Ardahan, F. ve Çalışkan, A. (2017). Bireyleri spor festivaline katılmaya motive eden faktörlerin çeşitli demografik değişkenlere ve yıllara göre karşılaştırılması: RUNATOLIA'ya örneği . Journal of Human Sciences, 14(2): 2149- 2177. doi:10.14687/jhs.v14i2.4434 https://doi.org/10.14687/jhs.v14i2.4434

Ardahan, F. ve Güleç, S. (2017). Developing and Doing Validity and Reliability of the Motivational Factors Scale of Recreational Motorcycle Usage. 5th International Academic Conference on Social Sciences. Proceedings Book. 27-28 th July 2017, Barcelona, Spain.

Ardahan, F. ve Güleç, S. (2017). Developing and Doing Validity and Reliability of the Motivational Factors Scale of Recreational Motorcycle Usage. 5th International Academic Conference on Social Sciences. Proceedings Book. 27-28 th July 2017, Barcelona, Spain.

Ardahan, F. ve Güleç, S. (2018). Bireyleri Motosiklet Kullanmaya Motive Eden Faktörlerin Çeşitli Değişkenlere Göre Karşılaştırılması. Uluslararası Rekreasyon ve Spor Yönetimi Kongresi. 10 - 13 Mayıs 2018, La Blanche Island Hotel, Bodrum, Muğla, Türkiye.

Ardahan, F. ve Mert, M. (2014). Bisiklet Kullanan Bireylerin Profillerinin Belirlenmesi ve Bireyleri Bisiklet Kullanmaya Motive Eden Faktörlerin Çeşitli Demografik Değişkenlere Göre Değerlendirilmesi: Türkiye Örneği. Türkiye Klinikleri Spor Bilimleri Dergisi, 6(2): 5357.

Ardahan, F. ve Turgut, T. (2013). Motivational factors for recreational fishing, the profile and life satisfaction level of recreational fishers and non-participants of fishing in Turkey", Turkish Journal Of Sport And Exercise, 15(1): 58-72.

Ardahan, F., Turgut, T. ve Kaplan Kalkan, A. (2016). Her Yönüyle Rekreasyon. Ankara: Delta Yayıncılık. 
Arıcı, A.F. (2008). Okumayı Niye Sevmiyoruz? Ünversite Öğrencileriyle

Avcı, S., Yüksel, A. ve Akıncı, T. (2010). Okuma Alışkanlığı Kazandırmada Etkili Bir

Yöntem: Okuma Çemberi. M.Ü. Atatürk Eğitim Fakültesi Eğitim Bilimleri Dergisi.32:5-24.

Chang, H.L. ve Lai, C.Y. (2015). Using travel socialization and underlying motivations to better understand motorcycle usage in Taiwan. Accident Analysis and Prevention 79: 212220.

https://doi.org/10.1016/j.aap.2015.03.023

Christmas, S., Young, D., Cookson, R. ve Cuerden, R. (2009). Passion, Performance, Practicality: Motorcyclists' Motivations and Attitudes to Safety - Motorcycle Safety Research Project. Project Record: PPRO 4/001/043. Transport Research Laboratory. Department for Transport, Road User Safety.

Daniello, A., Gabler, H. ve Mehta, Y. (2009). Effectiveness of motorcycle training and licensing. Transportation Research Record: Journal of the Transportation Research Board, No. 2140, Transportation Research Board of the National Academies, Washington, D.C: pp. 206-213. DOI: $10.3141 / 2140-23$. https://doi.org/10.3141/2140-23

Duprey, R. (2017). 12 Motorcycle Statistics That'll Floor You. The facts that explain the changing face of the motorcycle industry and those who support it https://www.fool.com/investing/2017/03/05/7-motorcycle-statistics-thatll-floor-you.aspx.

Gabriëlle Stephanie, W.S. (2013). A Human Geographical Exploration of Adventure Motorcycling Freedom to move, freedom to feel, freedom to choose. Master Thessis of Science in Geography in the University of Hull, Cottingham, United Kingdom

Harrington M. ve Dawson D. (1995). Who Has it Best? Women's Labor Force Participation, Perceptions Of Leisure and Constraints To Leisure. Journal of Leisure Research. 27(1): 4-25. https://doi.org/10.1080/00222216.1995.11969974

Haworth, N. (2012). Powered two wheelers in a changing world - Challenges and opportunities. Accident Analysis and Prevention, 44(1), 12-18.

https://doi.org/10.1016/j.aap.2010.10.031

http://www.tuik.gov.tr/PreHaberBultenleri.do;jsessionid=LyWvhJDHZbw3rHNqZnQLv9Cy gjJF3PWTQ2jf3pH912Tv2xkJj3w1!116634633?id=27643

Huth, V., Füssl, E. ve Risser, R. (2014). Motorcycle riders' perceptions, attitudes and strategies: Findings from a focus group study. Transportation Research Part F: Traffic Psychology and Behaviour. 25:74-85.

https://doi.org/10.1016/j.trf.2014.05.004

Year 4/ 2020, Volume-4, Issue-3 | WWW.ispecjournal.org 
Ibrahim H. ve Cordes K.A. (2002). Outdoor Recreation, Enrichment for a Lifetime. Second Edition, Sagamore Publishing, Il, p. 5-150.

Ibrahim H.ve Cordes K.A. (2002). Outdoor Recreation, Enrichment For a Lifetime. Urbana, IL.

Jackson, E.L. ve Henderson, K.A. (1995). Gender-Based Analysis of Leisure Constraints. Leisure Sciences. 17(1):31-51. https://doi.org/10.1080/01490409509513241

Kaplan Kalkan, A., Ardahan, F. (2013). Doğa Sporları Yapan Bireylerin Profilleri, Doğa Sporu Yapma Nedenleri ve Elde Ettikleri Faydalar: Antalya Örneği, Giresun Üniversitesi, Sosyal Bilimler Enstitüsü, Karadeniz Sosyal Bilimler Dergisi, 8(1):93-114.

Koçak, S., Uçar, K., Bayır, A. ve Ertekin, B. (2010). Acil Servise Başvuran Motosiklet ve Bisiklet Kazası Olgularının Karakteristikleri. Türkiye Acil Tıp Dergisi.10(3):112-118

Krige, M. (1995). Quantitative report on the profile of Australian motorcycle riders, Public Education Market Research Report 2/95. Canberra: Federal Office of Road Safety.

Mülakatlar. Mustafa Kemal Üniversitesi Sosyal Bilimler Enstitüsü Dergisi. 5(10):90-100.

Powell, R.A. (2017). Altruism in the American Motorcycle Culture: An Exploration of Organizational Citizen Behaviors and Impression Management. Doctoral dissertation. The School of Communication and the Arts, Regent University. ProQuest NUmber: 10273613.

Schneider IV, W. H., Savolainen, P. T., Van Boxel, D. ve Beverley, R. (2012). Examination of factors determining fault in two-vehicle motorcycle crashes. Accident Analysis \& Prevention. 45:669-676.

https://doi.org/10.1016/j.aap.2011.09.037

Steg, L. (2005). Car use: lust and must. Instrumental, symbolic and affective motives for car use. Transportation Research Part A 39: 147-162.

https://doi.org/10.1016/j.tra.2004.07.001

Steg, L., Geurs, K. ve Ras, M. (2001). The Effect of Motivational Factors on Car Use: A Multidisciplinary Modelling Approach. Transportation Research Part A 35: 789-806. https://doi.org/10.1016/S0965-8564(00)00017-3

Strutter, E. (2010). Sons of Anarchy (Season III). New York, NY: FX Network.

TUIK (2018a). Türkiye İstatistik Kurumu, Yıllara Göre Motorlu Kara Taşıtları Sayısı. 
TUIK (2018b). Türkiye İstatistik Kurumu, 2018-Şubat ayına göre Motorlu Kara Taşııtları Sayıs1.

http://www.tuik.gov.tr/PreHaberBultenleri.do;jsessionid=LyWvhJDHZbw3rHNqZnQLv9Cyg jJF3PWTQ2jf3pH912Tv2xkJj3w1!116634633?id=27643

TUIK (2018c) Motorlu Kara Taşıtları, İllere göre motorlu kara tașıtları sayıs1 http://www.tuik.gov.tr/PreHaberBultenleri.do?id=27642

https://www.motorcular.com/tr/moto-bilgi/motosikletin-tarihi- (Okunma Tarihi: 7 Nisan 2018)

http://www.forumgercek.com/motor-sporlari-motorsiklet-dunyasi/40343-motosiklet-tarihi-vekronolojsi.html (Okunma Tarihi: 7 Nisan 2018)

https://www.tmf.org.tr/tmf/tmf-hakkinda/

http://www.tuik.gov.tr/PreHaberBultenleri.do?id=24606

http://www.motosiklet.net/forum/moto-sohbet/145396-turkiye-ve-dunyada-trafik-kazaistatistikleri-olum-oranlari-vs-2007-2013-icerir.html (Okunma Tarihi: 9 Nisan 2018) http://www.uludag.edu.tr/dosyalar/ziraat/EgitiminOnemi.pdf (Okunma Tarihi: 9 Nisan 2018) https://www.motorcular.com/tr/moto-bilgi/motosiklet-turleri (Okunma Tarihi: 9 Nisan 2018) https://www.bizevdeyokuz.com/motosiklet-cesitleri// (Okunma Tarihi: 9 Nisan 2018) https://www.statista.com/statistics/183549/us-sales-of-motorcycles-since-1990/ https://www.statista.com/statistics/255516/us-motorcycle-bicycle-and-parts-manufacturinggross-output/ 